\title{
Soehngenia saccharolytica gen. nov., sp. nov. and Clostridium amygdalinum sp. nov., two novel anaerobic, benzaldehyde-converting bacteria
}

\author{
Sofia N. Parshina, ${ }^{1,2,3}$ Robbert Kleerebezem, ${ }^{2}$ Jose Luis Sanz, ${ }^{3}$ \\ Gatze Lettinga, ${ }^{2}$ Alla N. Nozhevnikova, ${ }^{1}$ Nadezhda A. Kostrikina, ${ }^{1}$ \\ Anatoly M. Lysenko ${ }^{1}$ and Alfons J. M. Stams ${ }^{3}$ \\ ${ }^{1}$ Laboratory of Microbiology of Anthropogenic Environments, Institute of Microbiology, Russian \\ Academy of Sciences, Moscow, Russia \\ ${ }^{2,3}$ Subdepartment of Environmental Technology ${ }^{2}$ and Laboratory of Microbiology ${ }^{3}$, Wageningen \\ University, Wageningen, The Netherlands
}

Two anaerobic, benzaldehyde-converting bacteria were isolated from an anaerobic upflow anaerobic sludge bed (UASB)-reactor treating potato starch waste water. Strain BOR-Y ${ }^{\top}$ converted benzaldehyde to benzoate and benzylalcohol in approximately equimolar concentrations. Benzaldehyde conversion did not support growth. Strain BOR-Y ${ }^{\top}$ was Gram-positive and rod-shaped, and its cells were slightly thickened in the middle. The strain was a mesophilic spore-former that grew between 15 and $40^{\circ} \mathrm{C}$, with optimum growth at $30-37^{\circ} \mathrm{C}$. The optimum $\mathrm{pH}$ for growth was $\mathrm{pH} 7 \cdot 0$. Strain $\mathrm{BOR}-\mathrm{Y}^{\top}$ grew on a wide range of carbohydrates and some other carbon sources including yeast extract, cysteine and serine. The $G+C$ content of its DNA was 42 mol\%. According to physiological characteristics and 16S rRNA gene sequence analysis, confirmed by DNA-DNA hybridization with its phylogenetic neighbours, strain BOR-Y ${ }^{\top}$ belongs to a novel genus of cluster XII of the clostridia, namely Soehngenia; the name Soehngenia saccharolytica is proposed for the type species (type strain BOR-Y $Y^{\top}=D S M 12858^{\top}=A T C C$ BAA $-502^{T}$ ). Strain BR-10 $0^{\top}$ reduced benzaldehyde to benzylalcohol. This conversion was coupled to growth. In a medium containing yeast extract, the presence of benzaldehyde resulted in the accumulation of more than twofold more cells. Strain BR-10 ${ }^{\top}$ was a Gram-positive organism that was characterized by oval- or rod-shaped cells with oval ends, which occurred singly, in pairs or sometimes in chains. The strain was moderately thermophilic and grew between 20 and $60^{\circ} \mathrm{C}$, with optimum growth at $45^{\circ} \mathrm{C}$. The optimum $\mathrm{pH}$ for growth was between $\mathrm{pH} 7 \cdot 0$ and 7.5. Strain $\mathrm{BR}-10^{\top}$ grew on a wide range of carbon sources including carbohydrates, yeast extract, casein and some amino acids. The $\mathrm{G}+\mathrm{C}$ content of its DNA was $32 \mathrm{~mol} \%$. As determined by $16 \mathrm{~S}$ rRNA gene sequence analysis, strain $\mathrm{BR}-10^{\top}$ represents a novel species of cluster XIVa of the clostridia; the name Clostridium amygdalinum is proposed for this novel species (type strain BR-10 $0^{\top}=$ DSM $12857^{\top}=$ ATCC BAA $-501^{\top}$ ).

\section{INTRODUCTION}

Many anaerobic bacterial strains are able to convert aromatic aldehydes to other compounds (Krumholz \& Bryant, 1985; Lux et al., 1990; Sembring \& Winter, 1990; Lux \& Drake, 1992; Gößner et al., 1994). Moorella thermoacetica (formerly Clostridium thermaceticum) (Collins et al., 1994) and Clostridium formicaceticum were shown to oxidize

The GenBank/EMBL/DDBJ accession numbers for the 16S rDNA sequences of Soehngenia saccharolytica BOR-Y $Y^{\top}$ and Clostridium amygdalinum BR-10 ${ }^{\top}$ are $\mathrm{AY} 353956$ and $\mathrm{AY} 353957$, respectively.

Electron micrographs of Soehngenia saccharolytica BOR-Y $Y^{\top}$ (Fig. I) and Clostridium amygdalinum BR-10 $0^{\top}$ (Fig. II) are available in IJSEM Online. the aldehyde group of vanillin to the carboxyl level (Lux et al., 1990). Ruminococcus productus (formerly Peptostreptococcus productus) reduced the aldehyde group of vanillin when co-cultured with $\mathrm{CO}$ but was not capable of this reaction when vanillin was the sole substrate (Lux et al., 1990).

Clostridium aceticum oxidized aromatic aldehydes (Lux \& Drake, 1992). A few Desulfovibrio strains oxidized the aldehyde group of vanillin and other aromatic aldehydes with sulfate as an electron acceptor (Zellner et al., 1990). A limited number of the strains were tested for their ability to convert benzaldehyde. Clostridium acetobutylicum reduced benzaldehyde, but $10 \mathrm{mM}$ benzaldehyde caused inhibition of growth. This bacterium required the presence 
of glucose and butyrate in the medium (Green et al., 1994). Desulfovibrio desulfuricans both oxidized and reduced benzaldehyde in the presence of nitrate (Parekh et al., 1996).

In a previous study (Parshina et al., 2000), the isolation of two bacterial strains able to convert benzaldehyde in the absence of inorganic electron acceptors was described. The bacteria were isolated from an anaerobic upflow anaerobic sludge bed (UASB)-reactor treating potato starch waste water. One bacterium (strain BOR-Y ${ }^{\mathrm{T}}$ ) performs the dismutation of benzaldehyde to benzoate and benzylalcohol. The other bacterium (strain BR-10 ${ }^{\mathrm{T}}$ ) uses benzaldehyde as an electron acceptor resulting in the formation of benzylalcohol and obtains metabolic energy from this reaction. In a medium containing $1 \mathrm{~g}$ yeast extract $1^{-1}$, the addition of $10 \mathrm{mM}$ benzaldehyde resulted in a twofold higher number of strain BR-10 ${ }^{\mathrm{T}}$ cells. The mechanisms of benzaldehyde conversion by strains $\mathrm{BOR}-\mathrm{Y}^{\mathrm{T}}$ and $\mathrm{BR}-10^{\mathrm{T}}$ have not been described. Therefore, it was expected that the two strains represented novel micro-organisms.

In this report, we describe the phenotypic and phylogenetic characteristics of the mesophilic bacterium which converts benzaldehyde to benzoate and benzylalcohol (strain BOR$\mathrm{Y}^{\mathrm{T}}$ ) and of the moderately thermophilic bacterium able to reduce benzaldehyde to benzylalcohol (strain BR-10 $0^{\mathrm{T}}$ ). On the basis of their phenotypic and phylogenetic characteristics, it is proposed that these two bacteria be named Soehngenia saccharolytica and Clostridium amygdalinum, respectively.

\section{METHODS}

Organisms and isolation of the strains. An enrichment culture was obtained from a mesophilic laboratory-scale UASB-reactor treating potato starch waste water. The isolation of strains BOR-Y ${ }^{\mathrm{T}}$ and $\mathrm{BR}-10^{\mathrm{T}}$ from this enrichment has been described previously (Parshina et al., 2000). Clostridium ultunense $\mathrm{BS}^{\mathrm{T}}\left(\mathrm{DSM} 10521^{\mathrm{T}}\right.$ ) was kindly provided by $\mathrm{Dr}$ Anna Schnürer (Department of Microbiology, Swedish University of Agricultural Sciences, P.O. Box 7025, SE-750 07 Uppsala, Sweden); Tissierella creatinini DSM $9508^{\mathrm{T}}$ was obtained from the DSMZ (Deutsche Sammlung von Mikroorganismen und Zellkulturen, Braunschweig, Germany).

Media and cultivation. Different media were used for cultivation of the isolates and the culture collection strains. A bicarbonatephosphate-buffered medium was used. Medium preparation and cultivation of the isolates has been described previously (Parshina et al., 2000). Strain BOR-Y $Y^{\mathrm{T}}$ was grown at $30^{\circ} \mathrm{C}$ and strain BR-10 ${ }^{\mathrm{T}}$ was grown at $45^{\circ} \mathrm{C}$. The bacteria were cultivated routinely in $120 \mathrm{ml}$ serum bottles containing $50 \mathrm{ml}$ medium. The amount of inoculum used was 1-2\%. For G $+\mathrm{C}$ content and DNA-DNA hybridization analyses, strain BOR-Y $\mathrm{Y}^{\mathrm{T}}$ was grown with $2 \mathrm{~g}$ yeast extract $\mathrm{l}^{-1}$ plus $10 \mathrm{mM}$ glucose and strain BR-10 $0^{\mathrm{T}}$ was grown with $2 \mathrm{~g}$ yeast extract $1^{-1}$ plus $10 \mathrm{mM}$ crotonate. For the cultivation of Tissierella creatinini DSM $9508^{\mathrm{T}}$, Clostridium Reinforced Medium (CRM), pH 8·3, supplemented with $0.5 \mathrm{M}$ creatinine was used at $30^{\circ} \mathrm{C}$. CRM supplemented with $20 \mathrm{mmol}$ serine $1^{-1}, 20 \mathrm{mmol}$ threonine $1^{-1}$ and $5 \mathrm{~g}$ yeast extract $1^{-1}$ was used for cultivation of C. ultunense $\mathrm{BS}^{\mathrm{T}}$ at $37^{\circ} \mathrm{C}$.

Microscopy. Cell morphology of the isolates was investigated with a phase-contrast light microscope. Fine structure was studied using a JEM-100 electron microscope as described previously (Svetlichniy et al., 1991). Gram staining was done according to standard procedures (Doetsch, 1981).

Analytical methods. Aromatic compounds (benzaldehyde, benzoate and benzylalcohol) and volatile fatty acids were analysed as described previously (Parshina et al., 2000). Organic acids were analysed by HPLC (Merck) with an RI-detector. A Polyspher OAHY column ( 300 by $6.5 \mathrm{~mm}$ ) was used. Hydrogen and carbon dioxide were analysed by using a Chrompack gas chromatograph (CP9001) equipped with a TCD-detector. The stainless steel column was filled with Molsieve 13X (60-80 mesh). The TCD-detector run was at $100^{\circ} \mathrm{C}$; argon was used as the carrier gas. Sulfide was analysed by the method Trüper \& Schlegel (1964).

Determination of temperature and $\mathbf{p H}$ optima. For the determination of temperature optima, strain BOR-Y ${ }^{\mathrm{T}}$ was cultivated in a medium containing $2 \mathrm{~g}$ yeast extract $1^{-1}$ plus $2 \mathrm{~g}$ glucose $\mathrm{l}^{-1}$, and strain $\mathrm{BR}-10^{\mathrm{T}}$ was cultivated in a medium containing $2 \mathrm{~g}$ yeast extract $1^{-1}$ plus $10 \mathrm{mmol}$ crotonate $1^{-1}$. Strain BOR-Y ${ }^{\mathrm{T}}$ was incubated at $5-52{ }^{\circ} \mathrm{C}$ and strain $\mathrm{BR}-10^{\mathrm{T}}$ was incubated at $10-70{ }^{\circ} \mathrm{C}$. $\mathrm{pH}$ optima were determined by incubating strains BOR- $\mathrm{Y}^{\mathrm{T}}$ and $\mathrm{BR}-10^{\mathrm{T}}$ at 30 and $45{ }^{\circ} \mathrm{C}$, respectively, at initial $\mathrm{pH}$ values ranging from $\mathrm{pH} 5 \cdot 0$ to $9 \cdot 0$. The $\mathrm{pH}$ was adjusted by adding $6 \mathrm{M} \mathrm{HCl}$ or $6 \mathrm{M}$ $\mathrm{NaOH}$.

Physiological tests. The following substrates were tested as carbon and energy sources $\left(20 \mathrm{mmol}^{-1}\right.$ each, unless indicated): yeast extract $\left(2 \mathrm{~g} \mathrm{l}^{-1}\right)$, formate, acetate, propionate, isobutyrate, glucose, fructose, sucrose, xylose, arabinose, rhamnose, mannose, ribose, maltose, cellobiose, galactose, melibiose, lactose, cellulose, xylan, mannitol, casitone, inositol, methanol, ethanol, ethylene glycol, ethylamine, lactate, succinate, fumarate, crotonate, pyruvate, malate, starch $\left(2 \mathrm{~g} \mathrm{l}^{-1}\right)$, glycerol, cysteine, serine, arginine, leucine, glycine, alanine, glutamate, methionine, casein $\left(2 \mathrm{~g} \mathrm{l}^{-1}\right)$, casein hydrolysate $\left(2 \mathrm{~g} \mathrm{l}^{-1}\right)$, peptone $\left(2 \mathrm{~g} \mathrm{l}^{-1}\right)$, gelatin, betaine, $\mathrm{H}_{2} / \mathrm{CO}_{2}$ [80\%:20\% $(\mathrm{v} / \mathrm{v})$ in the gas phase], creatine and creatinine. To investigate the utilization of electron acceptors, strains were cultivated in a medium containing $2 \mathrm{~g}$ yeast extract $1^{-1}$. The following electron acceptors were tested: $\mathrm{Na}_{2} \mathrm{SO}_{4}(10 \mathrm{mM}), \mathrm{Na}_{2} \mathrm{SO}_{3}(2 \mathrm{mM})$, $\mathrm{Na}_{2} \mathrm{~S}_{2} \mathrm{O}_{3} \quad(10 \mathrm{mM}), \quad \mathrm{Na}_{2} \mathrm{~S}_{2} \mathrm{O}_{4}(10 \mathrm{mM}), \quad \mathrm{Na}_{2} \mathrm{~S}_{2} \mathrm{O}_{5} \quad(10 \mathrm{mM}), \quad \mathrm{S}^{0}$ $\left(2 \mathrm{~g} \mathrm{l}^{-1}\right)$ and $\mathrm{NaNO}_{3}\left(2 \mathrm{~g} \mathrm{l}^{-1}\right)$. To test the ability of molecular nitrogen fixation, the medium described by Skinner (1971) was used. Standard medium supplemented with $2 \mathrm{~g}$ yeast extract $1^{-1}$ plus $10 \mathrm{mM}$ pyruvate flushed with $\mathrm{N}_{2}$ served as a control. The aerotolerance of the strains was determined as described for Clostridium aerotolerans (van Gylswyk \& van der Toorn, 1987) in the medium supplied with $20 \mathrm{mM}$ glucose. The air was injected into the closed bottles through a membrane filter. The volume of the air was $0 \cdot 5-100 \%(\mathrm{v} / \mathrm{v})$.

Biochemical tests. Several physiological and biochemical characteristics of the cultures were analysed using API 20 E biochemical kits (Identification system for Enterobacteriaceae and other Gramnegative rods; bioMérieux). To test for the presence of catalase, cell material was exposed to $10 \% \mathrm{H}_{2} \mathrm{O}_{2}$.

Isolation of genomic DNA. Wet biomass was washed with a solution containing $0 \cdot 15 \mathrm{M} \mathrm{NaCl}$ and $0 \cdot 1 \mathrm{M}$ EDTA, $\mathrm{pH} 8 \cdot 0$, and transferred to a medium containing $0.6 \mathrm{M}$ sucrose, $0.015 \mathrm{M}$ Tris $/ \mathrm{HCl}$, $\mathrm{pH} 7 \cdot 5,0 \cdot 015 \mathrm{M} \mathrm{NaCl}$ and $0 \cdot 01 \mathrm{M}$ EDTA. The bacterial cell wall was digested by the addition of $50 \mathrm{mg}$ egg white lysozyme $\mathrm{ml}^{-1}$ (Fluka) to the suspension and incubation at $37^{\circ} \mathrm{C}$ for $1 \mathrm{~h}$ and subsequent addition of $1 \%$ SDS. Further purification was carried out according to previously described methods (Marmur, 1961; Marmur \& Doty, 1961).

DNA G+C content determination. This was done by thermal denaturation using a Pye Unicum SP 1800 spectrophotometer. The $\mathrm{G}+\mathrm{C}$ content (mol\%) was calculated as described by Owen et al. (1969). 
DNA-DNA hybridization. DNA homology was determined using the reassociation method described by De Ley et al. (1970).

$16 S$ rRNA gene sequence analysis. This was done at the DSMZ. Approximately $95 \%$ of the $16 \mathrm{~S}$ rRNA gene sequence of the strains was determined by direct sequencing of PCR-amplified 16S rDNA. Genomic DNA extraction, PCR-mediated amplification of the 16S rDNA and purification of the PCR products was carried out as described by Rainey et al. (1996). Purified PCR products were sequenced using the ABI PRISM Dye Terminator Cycle Sequencing Ready Reaction Kit (Applied Biosystems) as described in the manufacturer's protocol. Sequence reactions were determined with an Applied Biosystems 373A DNA Sequencer.

The resulting sequence data from the isolates were put into the alignment editor AE2 (Maidak et al., 1996), aligned manually and compared with representative $16 \mathrm{~S}$ rRNA gene sequences of organisms belonging to the clostridia. For comparison, 16S rRNA gene sequences were obtained from the EMBL database or RDP (Maidak et al., 1996). The 16S rRNA gene sequence similarity values were calculated by pairwise comparison of the sequences within the alignment. For construction of the phylogenetic dendrogram, the PHYLIP package (Felsenstein, 1993) was used: pairwise evolutionary distances were computed from percentage similarities by the correction method of Jukes \& Cantor (1969). Based on the evolutionary distance values, phylogenetic trees for strains $\mathrm{BOR}-\mathrm{Y}^{\mathrm{T}}$ and $\mathrm{BR}-10^{\mathrm{T}}$ (Figs 1 and 2, respectively) were constructed by the neighbor-joining method (Saitou \& Nei, 1987).

\section{RESULTS AND DISCUSSION}

\section{Isolation of strains BOR-Y $\mathbf{Y}^{\boldsymbol{T}}$ and $\mathrm{BR}-10^{\boldsymbol{T}}$}

The enrichment and isolation of strains BOR-Y ${ }^{\mathrm{T}}$ and BR$10^{\mathrm{T}}$ have been described previously (Parshina et al., 2000).

\section{Morphological characterization of strains BOR-Y ${ }^{\top}$ and BR-10 ${ }^{\top}$}

Strain BOR-Y'. Some morphological characteristics of strain BOR-Y $Y^{\mathrm{T}}$ can be found in the genus and species descriptions for Soehngenia and Soehngenia saccharolytica, respectively (see below). Strain BOR-Y ${ }^{\mathrm{T}}$ was rod-shaped; its cells were slightly thickened in the middle and occurred singly, in pairs or in chains [Fig. Ia, supplementary data (http://ijs.sgmjournals.org)]. In the early-exponential phase of growth, cells were slightly motile by means of peritrichous flagella, but older cells lost their motility (Fig. Ib, supplementary data). Electron micrographs of thin sections revealed a cell-wall architecture typical for Grampositive bacteria (Fig. Ic, supplementary data). Spores were formed in the medium supplemented with pyruvate and occasionally in the nitrogen-free medium. Colonies of strain BOR- $\mathrm{Y}^{\mathrm{T}}$ on agar were rhizoid, resembled a snowflake, were dark cream in colour and reached $1 \cdot 0-1 \cdot 2 \mathrm{~mm}$ in diameter.

Strain BR-10'. Some morphological characteristics of strain BR-10 $10^{\mathrm{T}}$ can be found in the species description for Clostridium amygdalinum (see below). The strain was Gram-positive (Fig. II, supplementary data), and motile in the early-exponential phase of growth. Cell chains, as well as swelling cells, were sometimes formed in the latestationary phase of growth. Round, free spores were observed only in the nitrogen-free medium. Colonies of strain $\mathrm{BR}-10^{\mathrm{T}}$ on agar were circular, about $1 \mathrm{~mm}$ in diameter, creamy with a yellowish elevated centre and had a slightly undulating margin.

\section{Physiological characterization and metabolism of strains BOR-Y $\mathbf{Y}^{\boldsymbol{T}}$ and BR-10}

Strain BOR-Y $\mathbf{Y}^{\mathbf{T}}$. Strain BOR-Y ${ }^{\mathrm{T}}$ grew at initial $\mathrm{pH}$ values of between $\mathrm{pH} 6.5$ and $7 \cdot 5$; the optimum $\mathrm{pH}$ for growth was around $7 \cdot 0$. The temperature range for growth was $15-40^{\circ} \mathrm{C}$; the optimum temperature for growth was 30 $37^{\circ} \mathrm{C}$. Strain BOR-Y $\mathrm{Y}^{\mathrm{T}}$ was anaerobic. A remarkable property of the strain was its aerotolerance. Strain BOR-Y ${ }^{\mathrm{T}}$ grew until $50 \%$ air in the gas phase at standing conditions in the medium supplemented with $20 \mathrm{mM}$ glucose without reductant; however, it did not grow in non-reduced medium under air. The strain was capable of molecular nitrogen fixation. After 2 weeks cultivation, good growth was observed in a medium without $\mathrm{NH}_{4} \mathrm{Cl}$, flushed with $\mathrm{N}_{2}$, supplemented with $10 \mathrm{mM}$ of pyruvate and $8 \mathrm{mg}$ yeast extract $1^{-1}$. The strain was able to convert benzaldehyde. In our previous study (Parshina et al., 2000), the conversion of benzaldehyde by strain $\mathrm{BOR}-\mathrm{Y}^{\mathrm{T}}$ was described in more detail. Strain BOR-Y ${ }^{\mathrm{T}}$ required yeast extract in the medium $\left(0 \cdot 2 \mathrm{~g} \mathrm{l}^{-1}\right)$, and higher concentrations $\left(1-2 \mathrm{~g} \mathrm{l}^{-1}\right)$ stimulated growth. In the medium supplemented with carbohydrates, fast cell lysis was observed at the stationary phase of growth. Strain BOR-Y ${ }^{\mathrm{T}}$ used a wide range of carbon and energy sources, but could not utilize formate, acetate, propionate, isobutyrate, butyrate, casitone, inositol, glycerol, methanol, ethanol, p-cresol, casein, peptone, gelatin, lactate, succinate, fumarate, $\mathrm{H}_{2}$ / $\mathrm{CO}_{2}$, creatine, creatinine, ethylene glycol, betaine, ethylamine, crotonate, arginine, leucine, glycine, alanine, glutamate, methionine or casein hydrolysate. The main products formed from the conversion of yeast extract were acetate, $\mathrm{H}_{2}$ and $\mathrm{CO}_{2}$. Products formed after fermentation of glucose were formate, $\mathrm{H}_{2}, \mathrm{CO}_{2}$, acetate and ethanol. Using the API $20 \mathrm{E}$ system, strain BOR-Y ${ }^{\mathrm{T}}$ showed $\beta$-galactosidase activity but no activity for arginine dihydrolase, lysine decarboxylase, ornithine decarboxylase, urease, tryptophan desaminase, gelatinase or cytochrome oxidase. It also had positive reactions for $\mathrm{H}_{2} \mathrm{~S}$ formation, indole and acetoin production, sorbitol and amygdalin fermentation and a negative reaction for citrate utilization.

Strain BR-10'. Strain BR-10 ${ }^{\mathrm{T}}$ grew between pH 6.5 and $8 \cdot 0$; the optimum $\mathrm{pH}$ for growth was $7 \cdot 0-7 \cdot 5$. The temperature range for growth was $20-60^{\circ} \mathrm{C}$; the optimum temperature for growth was $45^{\circ} \mathrm{C}$. The strain was aerotolerant. Growth occurred till $50 \%$ of air in the gas phase at standing conditions. The strain did not fix molecular nitrogen. Strain BR-10 ${ }^{\mathrm{T}}$ required yeast extract $\left(1-2 \mathrm{~g} \mathrm{l}^{-1}\right)$ in the medium. Benzaldehyde, sulfite and thiosulfate were used as electron acceptors. Hydrogen in the gas phase 
instead of $\mathrm{N}_{2}$ served as an additional electron donor and this resulted in the stimulation of benzaldehyde conversion. Strain $\mathrm{BR}-10^{\mathrm{T}}$ used a wide range of carbon and energy sources, but could not utilize formate, acetate, propionate, isobutyrate, butyrate, methanol, benzoate, fumarate, malate, succinate, $\mathrm{H}_{2} / \mathrm{CO}_{2}$, galactose, rhamnose, lactose, mannose, cellulose, casein, casein hydrolysate, gelatin, aspartate, creatine, creatinine, ethylene glycol, ethylamine, arginine, leucine, lysine, alanine, glycine, glutamate or methionine. The main products formed from the conversion of yeast extract were $\mathrm{H}_{2}, \mathrm{CO}_{2}$ and acetate. Products from glucose fermentation were ethanol, acetate, $\mathrm{H}_{2}$ and $\mathrm{CO}_{2}$. Using the API $20 \mathrm{E}$ system, strain BR$10^{\mathrm{T}}$ showed no $\beta$-galactosidase, arginine dihydrolase, lysine decarboxylase, ornithine decarboxylase, urease, tryptophan desaminase, gelatinase or cytochrome oxidase activity. It had positive reactions for $\mathrm{H}_{2} \mathrm{~S}$, indole and acetoin production, and sorbitol and amygdalin fermentation, and a weak-positive reaction for citrate utilization.

\section{Phylogenetic, G+C content and DNA-DNA hybridization analyses}

Strain BOR-Y $\mathbf{Y}^{\top}$. Comparative sequence analysis of the 16S rRNA gene sequence of strain BOR-Y $\mathrm{Y}^{\mathrm{T}}$ showed that it is a member of cluster XII of the clostridia (Collins et al., 1994) (Fig. 1). This cluster is very heterogeneous. Among the bacteria most closely related to strain $\mathrm{BOR}-\mathrm{Y}^{\mathrm{T}}$ in the phylogenetic tree are members of the genus of sporeforming bacteria Clostridium and non-spore-forming Eubacterium and Tissierella. Strain BOR-Y ${ }^{\mathrm{T}}$ showed highest sequence similarity with Tissierella creatinini DSM $9508^{\mathrm{T}}$ (93.6\%), Tissierella praeacuta NCTC $11158^{\mathrm{T}}(93 \cdot 1 \%)$, Tissierella creatinophila DSM $6911^{\mathrm{T}}(93 \cdot 1 \%)$, Clostridium hastiforme DSM $5675^{\mathrm{T}}(93 \cdot 2 \%)$ and C. ultunense DSM $10521^{\mathrm{T}}(92 \cdot 2 \%)$. Sequence similarity values of less than $97 \%$ (Stackebrandt \& Goebel, 1994) justify the creation of a novel species for strain BOR-Y ${ }^{\mathrm{T}}$.

The $\mathrm{G}+\mathrm{C}$ content of the DNA of strain BOR-Y ${ }^{\mathrm{T}}$ was $43 \mathrm{~mol} \%$.

DNA-DNA hybridization of strain BOR-Y ${ }^{\mathrm{T}}$ with $C$. ultunense $\mathrm{BS}^{\mathrm{T}}$ and Tissierella creatinini DSM $9508^{\mathrm{T}}$ revealed reassociation values of 9 and $13 \%$, respectively. A DNA similarity value below $20 \%$ is an indicator for a novel genus (Johnson, 1984).

Strain BR-10 ${ }^{\top}$. According to the results of a phylogenetic analysis, strain BR- $10^{\mathrm{T}}$ falls into cluster XIVa of the clostridia (Collins et al., 1994), with highest sequence similarity (97-98\%) with a few representatives of the genus Clostridium (Fig. 2). Strain BR-10 $0^{\mathrm{T}}$ also showed $98 \%$ sequence similarity with the sulfate-reducing bacterium Desulfotomaculum guttoideum (Gogotova \& Vainstein, 1983), but it does not use sulfate and thus does not belong to the genus Desulfotomaculum. All other phylogenetic neighbours belong to the genus Clostridium.

The $\mathrm{G}+\mathrm{C}$ content of the DNA of strain $\mathrm{BR}-10^{\mathrm{T}}$ was $32 \mathrm{~mol} \%$.

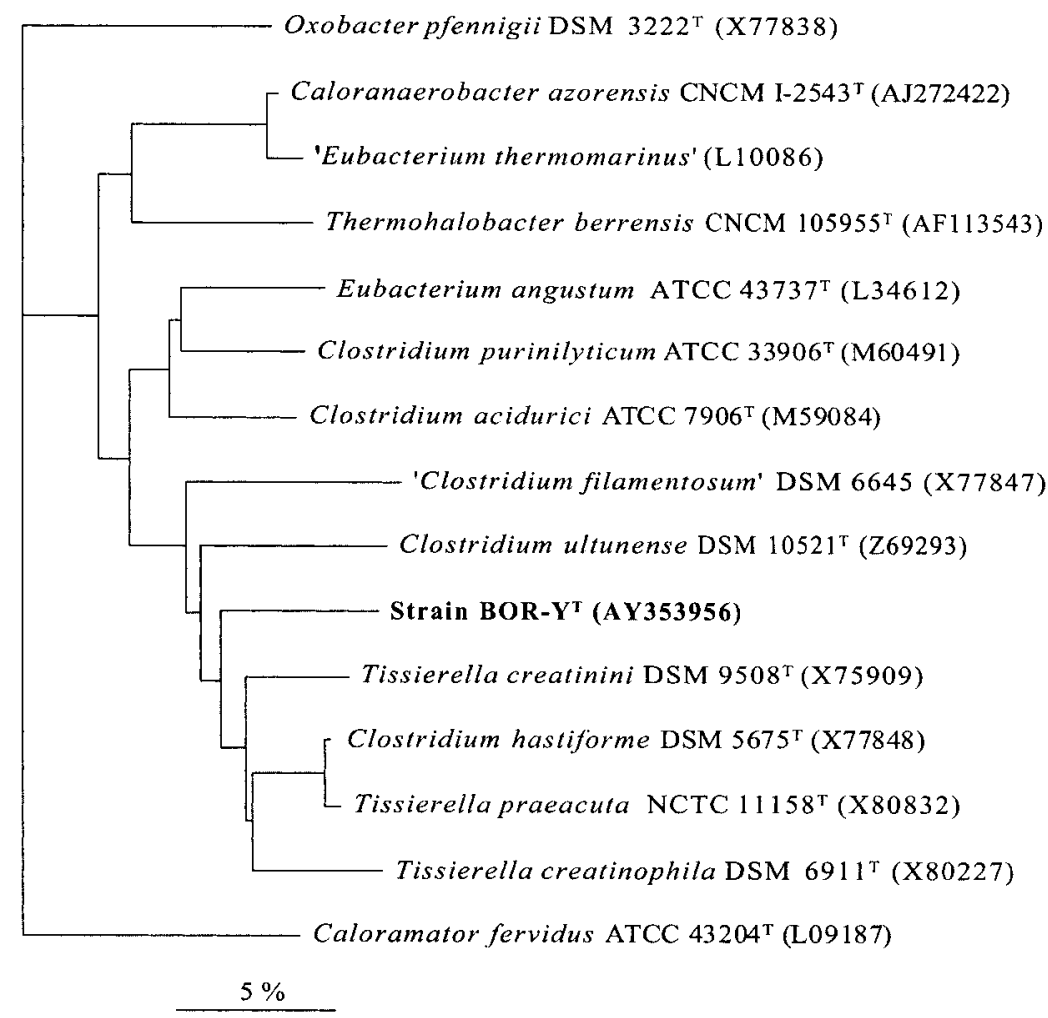

Fig. 1. Phylogenetic tree showing the position of strain BOR- $Y^{\top}$ among representatives of cluster XII of the clostridia (Collins et al., 1994). The tree is based on a distance matrix of $16 \mathrm{~S}$ rRNA gene sequences and was constructed using the neighbor-joining method (Saitou \& Nei, 1987), corrected by the method of Felsenstein (1993). The $16 \mathrm{~S}$ rRNA gene sequence of Caloramator fervidis was used to root the tree. Bar, sequence divergence. 


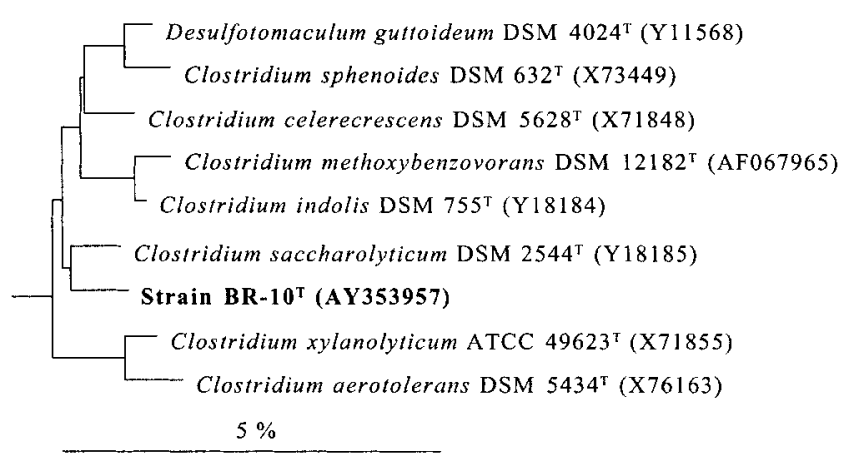

Fig. 2. Phylogenetic tree showing the position of strain $B R-10^{\top}$ among representatives of cluster XIVa of the clostridia (Collins et al., 1994). The tree is based on a distance matrix of 16S rRNA gene sequences and was constructed using the neighbor-joining method (Saitou \& Nei, 1987), corrected by the method of Felsenstein (1993). Bar, sequence divergence.

\section{Comparison of strains BOR-Y $\mathbf{Y}^{\top}$ and $B R-10^{\top}$ with related strains}

Strain BOR-Y $\mathbf{Y}^{\boldsymbol{T}}$. Table 1 gives characteristics useful for distinguishing strain BOR- $\mathrm{Y}^{\mathrm{T}}$ from related species.

C. aerotolerans can grow in media without added reducing agent but exposed to air (van Gylswyk \& van der Toorn, 1987). The acetogens Sporomusa silvacetica, M. thermoacetica,
Clostridium magnum, Acetobacterium woodii and Thermoanaerobacter kivui grow in semi-solid and liquid cultivation media containing $\mathrm{O}_{2}$, consume small amounts of $\mathrm{O}_{2}$ and do not lose the ability to synthesize acetate via the acetyl CoA pathway (Karnholz et al., 2002). Strain BOR-Y $\mathrm{Y}^{\mathrm{T}}$ is aerotolerant. It can grow till $50 \%$ of air in the gas phase. Aerotolerance is not an unusual property of anaerobic bacteria. Nevertheless, no one strain from cluster XII of the clostridia has been reported as being aerotolerant until now. In addition to the traits shown in Table 1, C. ultunense (Schnürer et al., 1996) differs from strain $\mathrm{BOR}-\mathrm{Y}^{\mathrm{T}}$ by its inability to grow on fructose and its production of acetate, formate, $\mathrm{H}_{2}$ and $\mathrm{CO}_{2}$ from glucose fermentation. C. hastiforme (Holdeman et al., 1977; Cato et al., 1982; Suen et al., 1988) is proteolytic, but not saccharolytic, unlike strain BOR-Y ${ }^{\mathrm{T}}$. In addition to the traits shown in Table 1, Tissierella creatinini DSM $9508^{\mathrm{T}}$ differs from strain BOR-Y ${ }^{\mathrm{T}}$ in that it grows on $\mathrm{N}$ methylhydantoin, and does not use carbohydrates or various other substrates including threonine (Gauglitz, 1988; Hermann et al., 1992), while Tissierella creatinophila (Harms et al., 1998) utilizes creatinine via creatine and does not grow on carbohydrates. Tissierella praeacuta (Tissier, 1908; Cato et al., 1979; Collins \& Shah, 1986; Farrow et al., 1995) is Gram-negative, and is weakly or non-fermentative.

On the basis of its phylogenetic, genetic and physiological

Table 1. Characteristics useful for distinguishing strain $B O R-Y^{\top}$ from related species

Strain/species: 1, strain BOR-Y ${ }^{\mathrm{T}}$ (this study); 2, Tissierella creatinini DSM 9508 ${ }^{\mathrm{T}}$ (Gauglitz, 1988; Hermann et al., 1992); 3, Tissierella praeacuta (Tissier, 1908; Cato et al., 1979; Collins \& Shah, 1986; Farrow et al., 1995); 4, Tissierella creatinophila (Harms et al., 1998); 5, C. hastiforme (Holdeman et al., 1977; Cato et al., 1982; Suen et al., 1988); 6, C. ultunense (Schnürer et al., 1996). -, Negative; +, positive; $\mathrm{NR}$, not reported; w, weak.

\begin{tabular}{|c|c|c|c|c|c|c|}
\hline Characteristic & 1 & 2 & 3 & 4 & 5 & 6 \\
\hline Formate & - & - & - & + (with creatinine) & NR & + \\
\hline Glucose & + & - & - & - & - & + \\
\hline Sucrose & + & - & - & - & - & - \\
\hline Betaine & - & - & NR & - & NR & + \\
\hline Ethylene glycol & - & NR & NR & NR & NR & + \\
\hline Cysteine & $\mathrm{w}$ & NR & $\mathrm{NR}$ & NR & NR & + \\
\hline Arginine & - & - & NR & - & + & NR \\
\hline Serine & + & - & NR & - & + & - \\
\hline Creatine & - & - & NR & + & - & NR \\
\hline Colonies & $\begin{array}{l}\text { Rhizoid, resemble } \\
\text { snow-flakes, } \\
\text { dark cream }\end{array}$ & $\mathrm{NR}$ & $\begin{array}{l}\text { Pinpoint, circular, } \\
\text { translucent, } \\
\text { colourless }\end{array}$ & $\begin{array}{l}\text { Circular, flat with } \\
\text { rough surface, } \\
\text { greyish and milky }\end{array}$ & $\begin{array}{l}\text { Pinpoint, circular, entire, } \\
\text { convex to peaked, opaque, } \\
\text { greyish-white }\end{array}$ & $\begin{array}{c}\text { Disk-shaped, } \\
\text { whitish }\end{array}$ \\
\hline
\end{tabular}


Table 2. Characteristics useful for distinguishing strain $B R-10^{\top}$ from related species

Strain/species: 1, Strain BR-10 ${ }^{\mathrm{T}}$ (this study); 2, C. saccharolyticum (Murray et al., 1982); 3, Clostridium xylanolyticum (Rogers \& Baecker, 1991); 4, C. aerotolerans (van Gylswyk \& van der Toorn, 1987; Chamkha et al., 2001); 5, Clostridium sphenoides (Walther et al., 1977); 6, Clostridium celerecrescens (Palop et al., 1989; Chamkha et al., 2001); 7, C. indolis (McClung \& McCoy, 1957; Corry, 1978); 8, C. methoxybenzovorans (Mechichi et al., 1999). +, Positive; NR, not reported; -, negative; W, weak.

\begin{tabular}{|c|c|c|c|c|c|c|c|c|}
\hline Characteristic & 1 & 2 & 3 & 4 & 5 & 6 & 7 & 8 \\
\hline \multicolumn{9}{|l|}{ Utilization of: } \\
\hline Pyruvate & + & + & $\mathrm{NR}$ & NR & + & - & + & - \\
\hline Glucose & + & + & + & + & + & + & + & + \\
\hline Arabinose & + & + & - & + & + & + & NR & - \\
\hline Xylose & + & + & + & + & + & + & NR & - \\
\hline Galactose & - & + & $\mathrm{NR}$ & + & $\mathrm{NR}$ & + & NR & + \\
\hline Rhamnose & - & + & + & + & + & + & NR & NR \\
\hline Lactose & - & + & NR & + & + & $\mathrm{W}$ & NR & + \\
\hline Mannose & - & + & + & + & + & + & NR & NR \\
\hline Xylan & + & $\mathrm{NR}$ & + & + & $\mathrm{NR}$ & NR & NR & - \\
\hline Mannitol & + & + & - & - & + & + & NR & $\mathrm{NR}$ \\
\hline Gelatin & - & NR & - & - & - & + & NR & - \\
\hline Cellulose & - & - & - & - & - & + & NR & - \\
\hline Starch & + & - & NR & NR & - & - & NR & $\mathrm{NR}$ \\
\hline Methanol & - & $\mathrm{NR}$ & $\mathrm{NR}$ & $\mathrm{NR}$ & $\mathrm{NR}$ & NR & NR & + \\
\hline Crotonate & + & $\mathrm{NR}$ & NR & NR & $\mathrm{NR}$ & NR & NR & - \\
\hline Betaine & + & $\mathrm{NR}$ & $\mathrm{NR}$ & $\mathrm{NR}$ & $\mathrm{NR}$ & NR & NR & + \\
\hline $\mathrm{H}_{2} / \mathrm{CO}_{2}$ & - & $\mathrm{NR}$ & NR & NR & NR & NR & NR & + \\
\hline Temp. opt. $\left({ }^{\circ} \mathrm{C}\right)$ & 45 & 37 & 35 & $22-38$ & $30-37$ & 35 & 37 & 37 \\
\hline pH opt. & $7 \cdot 4$ & $7 \cdot 4$ & $7 \cdot 0-7 \cdot 2$ & $7 \cdot 0$ & NR & $7 \cdot 0$ & NR & $7 \cdot 4$ \\
\hline $\mathrm{G}+\mathrm{C}$ content $(\mathrm{mol} \%)$ & 32 & 28 & 40 & 40 & 41 & 38 & 44 & 44 \\
\hline
\end{tabular}

properties, we propose to create a novel genus, Soehngenia, and a novel species, Soehngenia saccharolytica, to accommodate strain BOR-Y $\mathrm{Y}^{\mathrm{T}}$.

Strain BR-10'. Table 2 gives characteristics useful for distinguishing strain BR-10 $10^{\mathrm{T}}$ from related species.

Species of cluster XIVa of the clostridia are saccharolytic, but the types of sugars used by the different species vary (Table 2). In addition to the traits shown in Table 2, Clostridium saccharolyticum differs from strain BR-10 ${ }^{\mathrm{T}}$ in that it is Gram-negative, its cells are shorter $(0 \cdot 6-3 \cdot 0 \mu \mathrm{m})$, it is non-motile and it has no flagella. Strain $B R-10^{\mathrm{T}}$ is moderately thermophilic (optimum temperature is $45^{\circ} \mathrm{C}$ ): all species closely related to it are mesophilic. C. aerotolerans can grow in a non-reduced medium, exposed to air. Strain BR $-10^{\mathrm{T}}$ is aerotolerant, but can grow only till $50 \%$ of air in the gas phase. As mentioned above, the aerotolerance of the anaerobic acetogenic bacteria $S$. silvacetica, $M$. thermoacetica, C. magnum, A. woodii and Thermoanaerobacter kivui has been determined. In these bacteria, as in strains $\mathrm{BOR}-\mathrm{Y}^{\mathrm{T}}$ and $\mathrm{BR}-10^{\mathrm{T}}$, catalase activity was not detected (Karnholz et al., 2002). For optimal growth, strain BR $-10^{\mathrm{T}}$ requires $1-2 \mathrm{~g}$ yeast extract per litre of medium: all referred strains of cluster XIVa need 1-5 g yeast extract $1^{-1}$. Strain BR-10 ${ }^{\mathrm{T}}$ uses benzaldehyde as an electron acceptor and forms benzylalcohol during growth on yeast extract or other electron donors. Clostridium methoxybenzovorans oxidizes methoxylated aromatic compounds, with an aldehyde group to their corresponding carboxylic derivatives (Mechichi et al., 1999). Strain BR-10 ${ }^{\mathrm{T}}$ can use sulfite and thiosulfate as electron acceptors: this property has not been reported for any of the species closely related to it. Clostridium indolis is poorly described, but known properties are distinct from those of strain BR-10 ${ }^{\mathrm{T}}$ (Table 2).

On the basis of its phylogenetic, genetic and physiological properties, we believe that strain $\mathrm{BR}-10^{\mathrm{T}}$ is clearly different from related species and can be considered as a novel species of Clostridium, namely, Clostridium amygdalinum.

\section{Description of Soehngenia gen. nov.}

Soehngenia [Soehn.ge'ni.a. N.L. fem. n. Soehngenia named in honour of Nicolas L. Soehngen, the founder and first head (1911-1937) of the Laboratory of Microbiology of Wageningen University, The Netherlands, where this strain was isolated and described].

Gram-positive. In the early-exponential phase of growth, cells are slightly motile by means of peritrichous flagella; older cells lose their motility. Rare terminal or subterminal spore formation. Mesophilic. Anaerobic, but aerotolerant. Fixes molecular nitrogen. Saccharolytic and weakly proteolytic. Major end products from yeast extract conversion are 
$\mathrm{H}_{2}, \mathrm{CO}_{2}$ and acetate. Products of glucose fermentation are formate, $\mathrm{H}_{2}, \mathrm{CO}_{2}$, acetate and ethanol.

Type species is Soehngenia saccharolytica.

\section{Description of Soehngenia saccharolytica gen. nov., sp. nov.}

Soehngenia saccharolytica (sac.cha.ro.ly'ti.ca. Gr. n. sakkharos sugar; Gr. adj. lytikos loosening, dissolving; N.L. fem. adj. saccharolytica sugar dissolving).

Has the features of the genus. Straight or slightly thickened at the middle rod-shaped cells $(0 \cdot 5-0 \cdot 7 \mu \mathrm{m}$ by $2-11 \mu \mathrm{m})$ that occur singly, in pairs or in chains. Cell chains are formed in the stationary phase of growth. Terminal or subterminal spores are formed occasionally on pyruvate medium or in nitrogen-free medium. Spores are round to oval in shape. Colonies on agar are rhizoid, resemble a snow-flake, are dark cream in colour and reach $1 \cdot 0-1 \cdot 2 \mathrm{~mm}$ in diameter. Fermentative metabolism. Able to grow till $50 \%$ of air in the gas phase. Sulfite and thiosulfate are weakly used as electron acceptors (reduced to $\mathrm{H}_{2} \mathrm{~S}$ ). Sulfate, dithionite, disulfite, sulfur and nitrate are not used as electron receptors. Benzaldehyde is dismutated to benzoate and benzylalcohol. Catalase-negative. Produces indole. Does not liquefy gelatin. Substrates used as carbon and energy sources include yeast extract, glucose, fructose, sucrose, xylose, arabinose, rhamnose, mannose, ribose, maltose, cellobiose, galactose, melibiose, lactose, cellulose, xylan, mannitol, pyruvate, malate, starch, cysteine and serine. Minor product from yeast extract is $\mathrm{NH}_{4}^{+}$. Moderate growth occurs in mineral medium supplemented with $0 \cdot 2 \mathrm{~g}$ yeast extract $\mathrm{l}^{-1}$. Abundant growth occurs in mineral medium with 2 g yeast extract $\mathrm{l}^{-1}$ or plus 10 mol glucose $\mathrm{l}^{-1}$ or some other carbohydrates. In medium supplemented with carbohydrates, cells lyse rapidly in the stationary phase of growth. Growth temperature range is $15-40{ }^{\circ} \mathrm{C}$; optimum growth at $30-37^{\circ} \mathrm{C}$. pH range for growth is $\mathrm{pH} 6 \cdot 0-7 \cdot 5$; optimum growth around $\mathrm{pH} 7 \cdot 0$.

The type strain is BOR-Y $\mathrm{Y}^{\mathrm{T}}\left(=\mathrm{DSM} 12858^{\mathrm{T}}=\right.$ ATCC BAA$502^{\mathrm{T}}$ ). Isolated from an anaerobic-digester sludge. $\mathrm{G}+\mathrm{C}$ content of its DNA is $43 \mathrm{~mol} \%$.

\section{Description of Clostridium amygdalinum sp. nov.}

Clostridium amygdalinum (a.myg.da.li'num. L. neut. adj. amygdalinum made from almonds, referring to the smell of benzaldehyde, which is reduced by the type strain).

Oval or straight rod-shaped cells $(0 \cdot 5-1 \cdot 0 \mu \mathrm{m}$ by $0 \cdot 5-$ $10 \mu \mathrm{m})$ that occur singly, in pairs or in chains. In the early-exponential phase of growth, cells are motile by means of one terminal flagellum; older cells lose their motility. Cell chains, as well as swelling cells, are formed in the late-stationary phase of growth. Round, free spores are formed only in nitrogen-free medium. Colonies on agar are circular, about $1 \mathrm{~mm}$ in diameter, cream in colour with a yellowish elevated centre and have a slightly undulated margin. Gram-positive. Anaerobic, but aerotolerant. Growth occurs till $50 \%$ of air in the gas phase. Does not fix molecular nitrogen. Obligate requirement for yeast extract $\left(1-2 \mathrm{~g} \mathrm{l}^{-1}\right)$ in the growth medium. Substrates used as carbon and energy sources include yeast extract, glucose, sucrose, fructose, ribose, arabinose, xylose, melibiose, maltose, cellobiose, crotonate, casitone, pyruvate, lactate, ethanol, inositol, glycerol, mannitol, xylan, betaine, starch, casein, cysteine, serine and threonine. Catalasenegative. Produces indole. Does not liquefy gelatin. Major products formed from yeast extract are $\mathrm{H}_{2}, \mathrm{CO}_{2}$ and acetate; minor amounts of propionate, butyrate and valerate are formed. Products from glucose fermentation are ethanol, acetate, $\mathrm{H}_{2}$ and $\mathrm{CO}_{2}$. Benzaldehyde, sulfite and thiosulfite are used as electron acceptors. Sulfate, dithionite, disulfite, sulfur and nitrate are not used as electron acceptors. Moderately thermophilic. Temperature range for growth is $20-60{ }^{\circ} \mathrm{C}$; optimum growth at $45^{\circ} \mathrm{C}$. $\mathrm{pH}$ range for growth is $\mathrm{pH} 6 \cdot 5-8 \cdot 0$; optimum growth at $\mathrm{pH} 7 \cdot 0-7 \cdot 5$.

The type strain is BR $-10^{\mathrm{T}}\left(=\mathrm{DSM} 12857^{\mathrm{T}}=\right.$ ATCC BAA$501^{\mathrm{T}}$ ). Isolated from an anaerobic-digester sludge. $\mathrm{G}+\mathrm{C}$ content of its DNA is $32 \mathrm{~mol} \%$.

\section{ACKNOWLEDGEMENTS}

We would like to thank Dr Hans Hippe (DSMZ) and Dr Anna Schnürer for providing of strains for DNA-DNA hybridization, Cathrin Spröer for sequence and phylogenetic analyses of strains BOR-Y ${ }^{\mathrm{T}}$ and BR-10 ${ }^{\mathrm{T}}$, and Professor Vladimir Gorlenko for helpful discussions. We thank Wim Roelofsen, Ilse Gerrits and Dr Caroline Plugge for their help in the analyses. This research was supported by The Netherlands Science Foundation (NWO) and the Russian Ministry of Science and INTAS project 96-1809.

\section{REFERENCES}

Cato, E. P., Holdeman, L. V. \& Moore, W. E. C. (1979). Proposal of neotype strains for seven non-saccharolytic Bacteroides species. Int J Syst Bacteriol 29, 427-434.

Cato, E. P., Hash, D. E., Holdeman, L. V. \& Moore, W. E. C. (1982). Electrophoretic study of Clostridium species. J Clin Microbiol 15, 688-702.

Chamkha, M., Garcia, J.-L. \& Labat, M. (2001). Metabolism of cinnamic acids by some Clostridiales and emendation of the descriptions of Clostridium aerotolerans, Clostridium celerecrescens and Clostridium xylanolyticum. Int J Syst Evol Microbiol 51, 2105-2111.

Collins, M. D. \& Shah, H. N. (1986). Reclassification of Bacteroides praeacutus Tissier (Holdeman and Moore) in a new genus, Tissierella, as Tissierella praeacuta comb. nov. Int J Syst Bacteriol 36, 461-463.

Collins, M. D., Lawson, P. A., Willems, A., Cordoba, J. J., FernandezGarayzabal, J., Garcia, P., Cai, J., Hippe, H. \& Farrow, J. A. E. (1994). The phylogeny of the genus Clostridium: proposal of five new genera and eleven new species combinations. Int J Syst Bacteriol 44, 812-826.

Corry, J. E. L. (1978). A review. Possible sources of ethanol ante- and post-mortem: its relationship to the biochemistry and microbiology of decomposition. J Appl Bacteriol 44, 1-56. 
De Ley, J., Cattoir, H. \& Reynaerts, A. (1970). The quantitative measurement of DNA hybridization from renaturation rates. Eur J Biochem 12, 133-142.

Doetsch, R. N. (1981). Determinative methods of light microscopy. In Manual Methods for General Bacteriology, pp. 21-23. Edited by P. Gerhardt, R. G. E. Murray, R. N. Costilow, E. W. Nester, W. A. Wood, N. R. Krieg \& G. B. Philips. Washington, DC: American Society for Microbiology.

Farrow, J. A. E., Lawson, P. A., Hippe, H., Gauglitz, U. \& Collins, M. D. (1995). Phylogenetic evidence that the Gram-negative nonsporulating bacterium Tissierella (Bacteroides) praeacuta is a member of the Clostridium subphylum of the Gram-positive bacteria and description of Tissierella creatinini sp. nov. Int J Syst Bacteriol 45, 436-440.

Felsenstein, J. (1993). PHYLIP (phylogeny inference package), version 3.5c. Department of Genetics, University of Washington, Seattle, USA.

Gauglitz, U. (1988). Anaerober mikrobieller Abbau von Kreatin, Kreatinin und N-Methylhydantoin. $\mathrm{PhD}$ thesis. Göttingen University, Göttingen, Germany.

Gogotova, G. I. \& Vainstein, M. B. (1983). The sporogenous sulfate reducing bacterium Desulfotomaculum guttoideum sp. nov. Mikrobiologiya 52, 789-793 (in Russian).

Gößner, A., Daniel, S. L. \& Drake, H. L. (1994). Acetogenesis coupled to the oxidation of aromatic aldehyde groups. Arch Microbiol 161, 126-131.

Green, E. M., Kalil, M. S., Williams, P. \& Stephens, G. M. (1994). Screening for reduction of aldehydes and ketones by solventogenic cultures of the strict anaerobe, Clostridium acetobutylicum. Biotechnol Tech 8, 733-738.

Harms, C., Schleicher, A., Collins, M. D. \& Andreesen, J. R. (1998). Tissierella creatinophila sp. nov., a Gram-positive, anaerobic, nonspore-forming, creatinine-fermenting organism. Int J Syst Bacteriol 48, 983-993.

Hermann, M., Knerr, H.-J., Mai, N., Groß, A. \& Kaltwasser, H. (1992). Creatinine and $N$-methylhydantoin degradation in two newly isolated Clostridium species. Arch Microbiol 157, 395-401.

Holdeman, L. V., Cato, E. P. \& Moore, W. E. (editors) (1977). Anaerobe Laboratory Manual, 4th edn, pp. 1-156. Blacksburg, VA: Virginia Polytechnic Institute and State University.

Johnson, J. L. (1984). Bacterial classification III. Nucleic acids in bacterial classification. In Bergey's Manual of Systematic Bacteriology, vol. 1, pp. 8-11. Edited by N. R. Krieg \& J. G. Holt. Baltimore: Williams \& Wilkins.

Jukes, T. H. \& Cantor, C. R. (1969). Evolution of protein molecules. In Mammalian Protein Metabolism, pp. 21-132. Edited by H. N. Munro. New York: Academic Press.

Karnholz, A., Küsel, K., Gößner, A., Schramm, A. \& Drake, H. L. (2002). Tolerance and metabolic response of acetogenic bacteria toward oxygen. Appl Environ Microbiol 68, 1005-1009.

Krumholz, L. R. \& Bryant, M. P. (1985). Clostridium pfennigii sp. nov. uses methoxyl groups of monobenzenoids and produces butyrate. Int J Syst Bacteriol 35, 454-456.

Lux, M. F. \& Drake, H. L. (1992). Reexamination of the metabolic potentials of the acetogens Clostridium aceticum and Clostridium formicoaceticum: chemolithoautotrophic and aromatic-dependent growth. FEMS Microbiol Lett 95, 49-56.

Lux, M. F., Keith, E., Hsu, T. D. \& Drake, H. L. (1990). Biotransformations of aromatic aldehydes by acetogenic bacteria. FEMS Microbiol Lett 67, 73-78.

Maidak, B. L., Olsen, G. J., Larsen, N., Overbeek, R., McCaughey, M. J. \& Woese, C. R. (1996). The Ribosomal Database Project (RDP). Nucleic Acids Res 24, 82-85.
Marmur, J. (1961). A procedure for the isolation of deoxyribonucleic acid from micro-organisms. J Mol Biol 3, 208-218.

Marmur, J. \& Doty, P. (1961). Thermal denaturation of deoxyribonucleic acids. J Mol Biol 3, 585-594.

McClung, L. S. \& McCoy, E. (1957). Genus II Clostridium Prazmovski 1880. In Bergey's Manual of Determinative Bacteriology, 7th edn, pp. 634-693. Edited by R. S. Breed, E. G. D. Murray \& N. R. Smith. Baltimore: Williams \& Wilkins.

Mechichi, T., Labat, M., Patel, B. K. C., Woo, T. H. S., Thomas, P. \& Garcia, J.-L. (1999). Clostridium methoxybenzovorans sp. nov., a new aromatic $o$-demethylating homoacetogen from an olive mill wastewater treatment digester. Int $J$ Syst Bacteriol 49, 1201-1209.

Murray, W. D., Khan, A. W. \& van den Berg, L. (1982). Clostridium saccharolyticum sp. nov., a saccharolytic species from sewage sludge. Int J Syst Bacteriol 32, 132-135.

Owen, R. J., Hill, R. L. \& Lapage, S. P. (1969). Determination of DNA base composition from melting profiles in dilute buffers. Biopolymers 7, 503-516.

Palop, M. LL., Valles, S., Piñaga, F. \& Flors, A. (1989). Isolation and characterization of an anaerobic, cellulolytic bacterium, Clostridium celerecrescens sp. nov. Int J Syst Bacteriol 39, 68-71.

Parekh, M., Drake, H. L. \& Daniel, S. L. (1996). Bidirectorial transformation of aromatic aldehydes by Desulfovibrio desulfuricans under nitrate-dissimilating conditions. Lett Appl Microbiol 22, 115-120.

Parshina, S. N., Kleerebezem, R., van Kempen, E., Nozhevnikova, A. N., Lettinga, G. \& Stams, A. J. M. (2000). Benzaldehyde conversion by two anaerobic bacteria isolated from an upflow anaerobic sludge bed reactor. Process Biochem 36, 423-429.

Rainey, F. A., Ward-Rainey, N., Kroppenstedt, R. M. \& Stackebrandt, E. (1996). The genus Nocardiopsis represents a phylogenetically coherent taxon and a distinct actinomycete lineage: proposal of Nocardiopsaceae fam. nov. Int J Syst Bacteriol 46, 1088-1092.

Rogers, G. M. \& Baecker, A. A. W. (1991). Clostridium xylanolyticum sp. nov., an anaerobic xylanolytic bacterium from decayed Pinus patula wood chips. Int J Syst Bacteriol 41, 140-143.

Saitou, N. \& Nei, M. (1987). The neighbor-joining method: a new method for reconstructing phylogenetic trees. Mol Biol Evol 4, 406-425.

Schnürer, A., Schink, B. \& Svensson, B. H. (1996). Clostridium ultunense sp. nov., a mesophilic bacterium oxidizing acetate in syntrophic association with a hydrogenotrophic methanogenic bacterium. Int J Syst Bacteriol 46, 1145-1152.

Sembring, T. \& Winter, J. (1990). Demethylation of aromatic compounds by strain B 10 and complete degradation of methoxybenzoate in co-culture with Desulfosarcina strains. Appl Microbiol Biotechnol 33, 233-238.

Skinner, F. A. (1971). The isolation of soil bacteria. In Isolation of Anaerobes, pp. 57-78. Edited by D. A. Shapton \& R. G. Board. London: Academic Press.

Stackebrandt, E. \& Goebel, B. M. (1994). Taxonomic note: a place for DNA-DNA reassociation and $16 \mathrm{~S}$ rRNA sequence analysis in the present species definition in bacteriology. Int J Syst Bacteriol 44, 846-849.

Suen, J. C., Hatheway, C. L., Steigerwalt, A. G. \& Brenner, D. J. (1988). Clostridium argentinense sp. nov.: a genetically homogeneous group composed of all strains of Clostridium botulinum toxin type $G$ and some nontoxigenic strains previously identified as Clostridium subterminale or Clostridium hastiforme. Int J Syst Bacteriol 38, 375-381. 
Svetlichny, V. A., Sokolova, T. G., Gerhardt, M., Ringpfeil, M., Kostrikina, N. A. \& Zavarzin, G. A. (1991). Carboxydothermus hydrogenoformans gen. nov., sp. nov., a CO-utilizing thermophilic anaerobic bacterium from hydrothermal environments of Kunashir Island. Syst Appl Microbiol 14, 254-260.

Tissier, P. H. (1908). Recherches sur la flore intestinale normale des enfants âgés d'un an à cinq ans. Ann Inst Pasteur 22, 189-208.

Trüper, H. G. \& Schlegel, H. G. (1964). Sulfur metabolism in Thiorhodaceae. 1. Quantitative measurement of growing cells of Chromatium okenii. Antonie van Leeuwenhoek 30, 225-238. van Gylswyk, N. O. \& van der Toorn, J. J. T. K. (1987). Clostridium aerotolerans sp. nov., a xylanolytic bacterium from corn stover and from the rumina of sheep fed corn stover. Int J Syst Bacteriol 37, 102-105.

Walther, R., Hippe, H. \& Gottschalk, G. (1977). Citrate, a specific substrate for the isolation of Clostridium sphenoides. Appl Environ Microbiol 33, 955-962.

Zellner, G., Kneifel, H. \& Winter, J. (1990). Oxidation of benzaldehydes to benzoic acid derivatives by three Desulfovibrio strains. Appl Environ Microbiol 56, 2228-2233. 